\title{
PENANGGULANGAN GIZI BURUK MELALUI ANALISIS SIKAP DAN KEBIASAAN IBU DALAM PENGATURAN MAKANAN KELUARGA
}

\author{
(Preventing Malnutrition through Behavior Analysis and Family Food Management) \\ Elida $^{1^{*}}$ dan Lucy Fridayati ${ }^{1}$ \\ 1 Jurusan Kesejahteraan Keluarga FT UNP Padang. \\ * Alamat korespondensi: Jurusan Kesejahteraan Keluarga FT UNP Padang. Email: elida@yahoo.com
}

\begin{abstract}
The aim of this research is to analyze mother behavior and family food management to prevent malnutrition. The population of this research was mothers of malnourished children in Kuranji District of Padang City. As many as 65 mothers were taken using technique of random sampling. Results show that mother behavior and family food management were categorized as good and might not be responsible to the incidence of malnutrition.
\end{abstract}

Keyword: malnourished children, family food management.

\section{PENDAHULUAN}

\section{Latar Belakang}

Masalah gizi adalah masalah kesehatan masyarakat yang penanggulangannya tidak dapat dilakukan dengan pendekatan medis dan pelayanan kesehatan saja. Masalah gizi di samping berkaitan erat dengan kemiskinan serta ketahanan pangan di tingkat rumahtangga, juga menyangkut aspek pengetahuan dan perilaku yang kurang mendukung pola hidup sehat.

Timbulnya krisis ekonomi yang berkepanjangan telah membawa dampak terhadap peningkatan jumlah penduduk yang hidup dalam kemiskinan. Menurut UNICEF yang dikutip oleh Hartoyo (2002) menyatakan bahwa kemiskinan erat kaitannya dengan masalah defisiensi gizi. Penduduk yang miskin memiliki akses yang relative kecil terhadap pangan dan pelayanan kesehatan biasanya hidup dalam lingkungan yang kurang bersih dan beresiko terhadap penyakit. Oleh sebab itu, peningkatan jumlah penduduk miskin akan meningkatkan masalah yang berkaitan dengan gizi.

Salah satu masalah yang berkaitan dengan gizi adalah kekurangan gizi yang pada umumnya diderita balita. Kekurangan gizi pada balita dapat berakibat negatif terhadap pertumbuhan dan perkembangan intelektual anak di masa dewasanya, dengan kecepatan yang lebih lamban daripada pertumbuhan pada masa bayi, akan tetapi kegiatan fisik pada masa balita meningkat. Dengan demikian kebutuhan gizi pada anak-anak masih tetap tinggi. Berdasarkan hal tersebut maka akhimya dapat mengancam sumber daya manusia berkualitas dimasa yang akan datang serta tingginya angka kesakitan dan kemiskinan (Nasution, 1995)

Banyak hal yang menyebabkan terjadinya kekurangan gizi pada balita, bila kita kaitkan dengan beberapa temuan kasus sebab-akibat timbulnya masalah gizi dapat terjadi karena disebabkan oleh beberapa faktor. PERSAGI pada tahun 1999 menyatakan bahwa faktor yang menyebabkan gizi kurang adalah konsumsi makanan dan tingkat kesehatan, pendapatan keluarga, persediaan makanan dan kurang pendidikan dan keterampilan dalam pengaturan gizi atau makanan. (Nyoman, 2002).

Berdasarkan temuan Departemen Kesehatan (2004), pada tahun 2003 terdapat sekitar 27.5\% (5 juta balita kurang gizi), 3.5 juta anak (19.2\%) dalam tingkat gizi kurang, dan 1.5 juta anak gizi buruk (8,3\%). Temuan ini sudah termasuk di dalamnya Provinsi Sumatera Barat, padahal Sumatera Barat yang dikenal sebagai penghasil pangan di Indonesia, namun mempunyai penderita gizi buruk yang cukup tinggi. Berdasarkan data yang diperoleh dari Kantor Dinas Kesehatan Kota Padang tahun 2002, jumlah balita dengan status gizi buruk ternyata cukup tinggi yaitu 1406 balita yang tersebar di sebelas kecamatan. Dari informasi tersebut dapat diketahui bahwa Kota Padang masih memiliki penderita gizi buruk yang cukup tinggi.

Banyak penelitian yang telah dilakukan oleh peneliti yang berkaitan dengan masalah gizi buruk ini, diantaranya: Fridayati (1997), dan Liswarti dan Elida (2001) tentang masalah makanan tambahan dan busung lapar, tetapi yang meneliti tentang sikap dan kebiasaan ibu dalam mengatur gizi atau makanan keluarga 
belum ditemukan, padahal ibu mempunyai peranan yang sangat penting dalam mengatur makanan anak dan juga merupakan salah satu faktor penyebab terjadinya gizi buruk pada balita. Walaupun anak sudah memilih makanan yang disukai dan dibutuhkan tetapi mereka tetap memerlukan perhatian khusus agar makanan yang dikonsumsinya memenuhi kebutuhan tubuh, kalau tidak kekurangan gizi yang terusmenerus dan berlangsung lama dapat berakibat menjadi gizi buruk pada balita.

Berdasarkan hal tersebut maka peneliti tertarik untuk mempelajari prilaku ibu yaitu sikap dan kebiasaan ibu dalam pengaturan gizi atau makanan keluarganya. Dengan diperolehnya hal itu maka peneliti akan mencoba mencari jalan pemecahan dalam penanggulangan gizi buruk yang sesuai untuk mengubah sikap dan kebiasaan ibu rumahtangga dalam memenuhi kebutuhan gizi dan pengaturan makanan keluarga meliputi pengetahuan tentang zat-zat makanan, teknik pengolahan, cara penyajian dan pemberian makanan.

Berdasarkan penjelasan pada latar belakang masalah di atas, banyak faktor yang mem pengaruhi terjadinya gizi buruk pada balita salah satunya adalah sikap dan kebiasaan ibu dalam pengaturan makanan keluarganya, maka rumusan permasalahan dalam penelitian ini ialah: "Bagaimanakah sikap dan kebiasaan ibu rumahtangga dalam pengaturan makanan keluarga yang meliputi pengetahuan tentang zat makanan, pola makan, penyusunan menu, persiapan makanan, teknik pengolahan makanan, cara penyajian dan pemberian makanan.

Sejalan dengan latar belakang masalah, penelitian ini bertujuan untuk menganalisis dan mengungkapkan sikap dan kebiasaan Ibu dalam pengaturan makanan keluarga yang mempunyai balita dengan status gizi buruk yang meliputi: pengetahuan tentang zat-zat makanan, pola makanan, penyusunan menu, persiapan makanan, teknik pengolahan, cara penyajian dan pemberian makanan. Hasil penelitian diharapkan bermanfaat bagi beberapa pihak, diantaranya: (1) sebagai pedoman bagi ibu-ibu yang mempunyai balita penderita gizi buruk dalam pengaturan makanan di rumahtangga, (2) Dinas Kesehatan dan segala unsur di lingkungan kesehatan sebagai informasi yang dapat dilakukan dalam penanggulangan gizi buruk, (3) masukan bagi Pemerintah Kota Padang umumnya dan khususnya Kecamatan Kuranji sebagai informasi untuk memperbaiki status gizi buruk.

\section{METODE}

Jenis penelitian ini deskriptif kuantitatif yang bertujuan untuk menganalisis sikap dan kebiasaan Ibu dalam pengaturan makanan keluarga Populasi penelitian ini bersifat homogen yaitu seluruh ibu-ibu yang mempunyai balita dengan status gizi buruk yang terdapat di kecamatan Kuranji, dengan jumlah 85 orang, jumlah sample 65 orang dengan teknik pengambilan sample simple random sampling. Tempat pelaksanaan penelitian dilakukan di Kecamatan Kuranji Kota Padang dengan waktu 6 bulan

Instrumen yang digunakan untuk mengumpulkan data penelitian berupa angket (kuesioner). Angket disusun dalam bentuk skala Likert dengan 5 alternatif jawaban. Pernyataan dalam kuisioner terdiri dari pernyataan positif dan negatif yaitu Sangat setuju (SS), Setuju (S), Netral (P), Tidak setuju (TS), Sangat Tidak Setuju (STS). Jenis data digunakan adalah data primer dan sekunder. Data primer adalah data tentang sikap dan kebiasaan ibu dalam pengaturan makanan keluarga yang diperoleh langsung dari responden dengan menyebarkan angket, dan data sekunder yaitu data tentang jumlah anak balita yang menderita gizi buruk. Pengolahan dan analisis data dilakukan secara deskriptif.

\section{HASIL DAN PEMBAHASAN}

\section{Karakteristik Responden}

Karakteristik responden yang dilibatkan dalam penelitian ini disajikan pada tabel 1 berikut.

\section{Sikap Ibu dalam Pengaturan Makanan Keluarga tentang Pengetahuan Zat-zat Makanan}

Berdasarkan analisis data sikap ibu dalam pengaturan makanan tentang pengetahuan zat-zat makanan menunjukan bahwa persentase nilai skor sangat baik dan baik sama yaitu $41 \%$, sedangkan yang mempunyai pengetahuan cukup $15.63 \%$, kurang $2 \%$ sedangkan sangat kurang $0.30 \%$. Berdasarkan hasil analisis data dapat digambarkan dengan Gambar 1 berikut.

Setelah harga rata-rata skor dikonsultasikan dengan tabel harga mean dapat disimpulkan bahwa sikap dan kebiasaan Ibu dalam pengaturan makanan keluarga ditinjau dari pengetahuannya tentang zat-zat makanan terbukti termasuk kategori sangat baik. 
Tabel 1. Karakteristik Responden

\begin{tabular}{|c|c|c|c|}
\hline Identitas Responden & Pilihan Jawaban & Frekuensi Jawaban & \% Frekuensi Jawaban \\
\hline \multirow[t]{4}{*}{ 1. Jumlah Anggota Keluarga } & 3 orang & 13 & 32.50 \\
\hline & 4 orang & 12 & 30.00 \\
\hline & 5 orang & 3 & 7.50 \\
\hline & $>5$ orang & 12 & 30.00 \\
\hline \multirow[t]{3}{*}{ 2. Jumlah Anak Balita } & 1 orang & 22 & 55.00 \\
\hline & 2 orang & 11 & 27.50 \\
\hline & 3 orang & 7 & 17.50 \\
\hline \multirow[t]{3}{*}{ 3. Usia Ayah/suami } & $20-25$ tahun & 3 & 7.50 \\
\hline & 26-30 tahun & 14 & 35.00 \\
\hline & >30 tahun & 23 & 57.50 \\
\hline \multirow[t]{3}{*}{ 4. Usia Ibu } & 20-25 tahun & 9 & 22.50 \\
\hline & 21-30 tahun & 15 & 37.50 \\
\hline & $>30$ tahun & 16 & 44.00 \\
\hline \multirow[t]{4}{*}{ 5. Pekerjaan Ayah } & PNS & 2 & 5.00 \\
\hline & Buruh & 13 & 32.50 \\
\hline & Swasta & 14 & 35.50 \\
\hline & Petani & 11 & 27.50 \\
\hline \multirow[t]{3}{*}{ 6. Pekerjaan Ibu } & RT & 32 & 80.00 \\
\hline & PNS & 5 & 12.50 \\
\hline & Swasta & 8 & 7.50 \\
\hline \multirow[t]{3}{*}{ 7. Pendidikan Ibu } & Tamat SD & 10 & 25.00 \\
\hline & Tamat SLTP & 16 & 40.00 \\
\hline & Tamat SLTK & 14 & 35.00 \\
\hline \multirow[t]{2}{*}{ 8. Penghasilan sebulan } & $<1000000$ & 14 & 35.00 \\
\hline & $>1000000$ & 26 & 65.00 \\
\hline
\end{tabular}

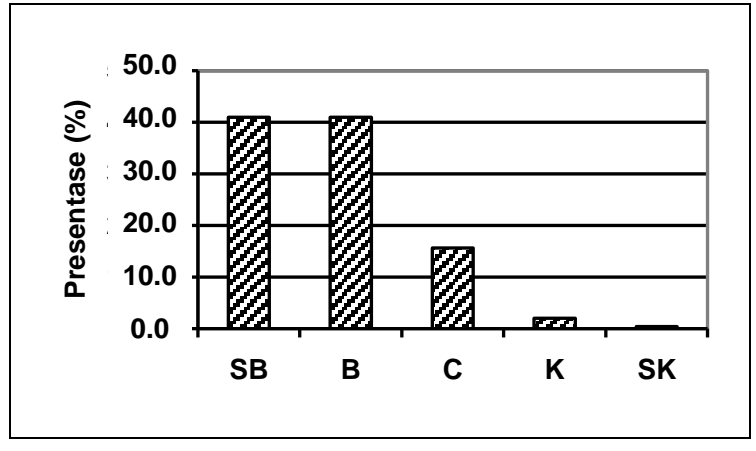

Gambar 1. Grafik Pegetahuan Tentang Zat-Zat Makanan

Sikap Ibu dalam Pengaturan Makanan Keluarga tentang Pola Makanan.

Berdasarkan analisis data tentang sikap ibu dalam pengaturan makanan tentang pola makan ditemukan $55 \%$ menunjukan sangat baik, $31.21 \%$ baik, $11.25 \%$ cukup, $2.50 \%$ kurang dan $0 \%$ sangat kurang. Hasil analisis dapat digambarkan dengan grafik berikut:

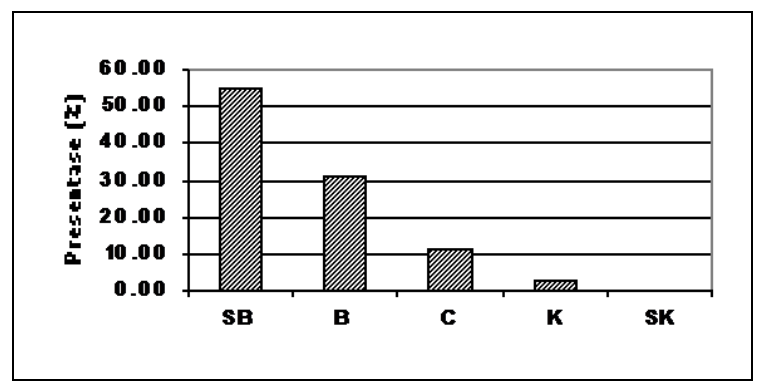

Setelah harga rata-rata skor dikonsultasikan dengan tabel harga mean, dapat disimpulkan bahwa sikap Ibu dalam pengaturan makanan keluarga tentang Pola Makan termasuk kategori sangat baik.

Sikap Ibu dalam Pengaturan Makanan Keluarga tentang Penyusunan Menu

Berdasarkan analisis data sikap ibu dalam pengaturan makanan tentang penyusunan menu ditemukan bahwa $29.50 \%$ sangat baik, $38.25 \%$ baik, $19 \%$ cukup, $7.25 \%$ kurang dan $6.00 \%$ sangat kurang. Hasil analisa dapat digambarkan dengan grafik berikut:

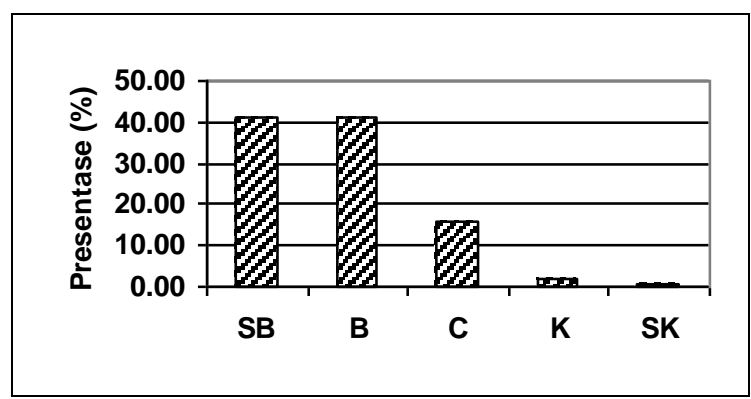

Gambar 3. Grafik Penyusunan Menu

Setelah harga rata-rata skor dikonsultasikan dengan tabel harga rata-rata, dapat disimpulkan bahwa sikap Ibu dalam pengaturan makanan keluarga tentang penyusunan menu termasuk kategori Baik

Gambar 2. Grafik Pola Makan 
Sikap Ibu dalam Pengaturan Makanan Keluarga tentang Persiapan Makanan.

Berdasarkan analisis data tentang sikap ibu dalam pengaturan makanan keluarga tentang persiapan makanan menunjukan bahwa 35.68 sangat baik, $35.63 \%$ baik, $15.00 \%$ cukup, $10.00 \%$ kurang dan $2.50 \%$ sangat kurang. Hasil analisis data dapat digambarkan dengan grafik berikut:

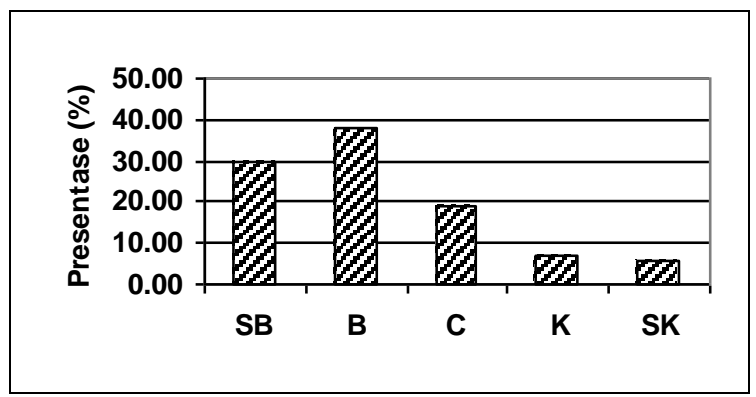

Gambar 4. Grafik Persiapan Makanan

Setelah harga rata-rata skor dikonsultasikan dengan tabel harga mean dapat disimpulkan bahwa sikap lbu dalam pengaturan makanan keluarga tentang persiapan makanan termasuk kategori Baik.

Sikap ibu dalam Pengaturan Makanan Keluarga tentang Teknik Pengolahan Makanan

Berdasarkan analisis data sikap ibu dalam pengaturan makanan keluarga tentang teknik pengolahan makanan adalah $12 \%$ sangat baik, $48.50 \%$ baik, 13.50 cukup, $19.00 \%$ cukup dan $7.00 \%$ sangat kurang. Hasil analisis data tersebut digambarkan dengan grafik berikut.

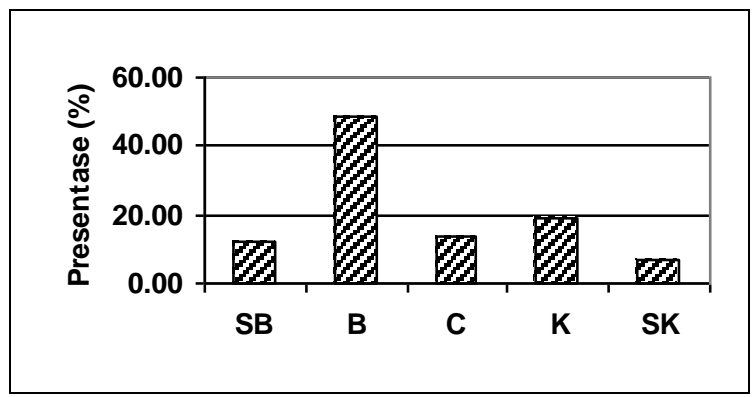

Gambar 5. Grafik Teknik Pengolahan Makanan

Setelah harga rata-rata skor dikonsultasikan dengan tabel harga mean dapat disimpulkan sikap ibu dalam pengaturan gizi/makanan keluarga tentang Teknik Pengolahan Makanan termasuk kategori Baik.
Sikap ibu dalam Pengaturan Makanan Keluarga tentang Cara Penyajian dan Pemberian Makanan.

Berdasarkan analisis data sikap ibu dalam pengaturan makanan keluarga tentang cara penyajian dan pemberian makanan adalah 48.33\% sangat baik, $39.79 \%$ baik, $10.63 \%$ cukup, $1.04 \%$ kurang dan $0.4 \%$ sangat kurang. Hasil data dapat digambarkan dengan grafik berikut.

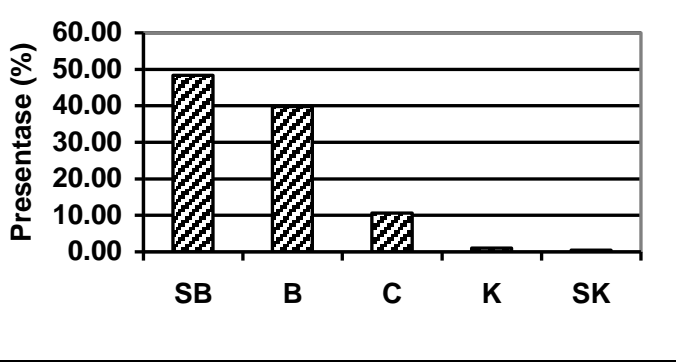

Gambar 6. Grafik Cara Penyajian dan Pemberian Makanan

Setelah harga rata-rata skor dikonsultasikan dengan tabel harga rata-rata (mean) dapat disimpulkan bahwa sikap Ibu dalam pengaturan makanan keluarga termasuk kategori sangat baik.

Sikap Ibu dalam Pengaturan Makanan Keluarga secara Keseluruhan

Berdasarkan analisis data sikap ibu dalam pengaturan makanan keluarga secara keseluruhan adalah $37.12 \%$ sangat baik, $39.07 \%$ baik, $14.17 \%$ cukup, $6.97 \%$ kurang dan $2.68 \%$ sangat kurang. Hasil data dapat digambarkan dengan grafik berikut.

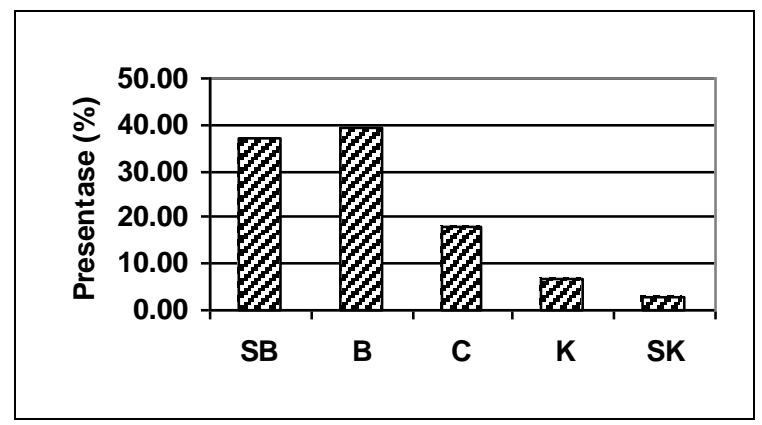

Gambar 7. Grafik Analisa Sikap Ibu dan Pengaturan Makanan Keluarga

Berdasarkan hasil pengolahan data analisis sikap Ibu dalam pengaturan makanan keluarga secara keseluruhan terlihat bahwa ratarata total 400, 99 : 100 hasilnya 4.01. setelah 
harga rata-rata total diperoleh kemudian dikonsultasikan dengan tabel harga mean dapat disimpulkan bahwa sikap ibu dalam pengaturan makanan keluarga termasuk kategori baik.

\section{Kebiasaan Ibu dalam Pengaturan Makanan Keluarga}

\section{Kebiasaan ibu dalam penyusunan menu}

Sudah sesuai dengan kebutuhan $75 \%$ dan $25 \%$ belum sesuai dengan kebutuhan. Masakan dan bahan makanan sudah bervariasi $80 \%$ dan $20 \%$ tidak bervariasi. Sesuai dengan biaya yang tersedia $90 \%$, sedangkan tidak sesuai dengan biaya tersedia $10 \%$. Sudah menyesuaikan dengan iklim dan musim 30\% dan tidak menyesuaikan $70 \%$. Disesuaikan dengan peralatan yang tersedia $87.50 \%$ dan yang tidak $12.50 \%$.

\section{Kebiasaan ibu dalam pembelian bahan makanan}

Setiap hari membeli dan membeli di pasar $17.50 \%$. Setiap hari dan membeli di warung $82.50 \%$.

\section{Persiapan bahan makanan}

Membersihkan sayuran dicuci dulu baru dipotong $62.50 \%$ dan dipotong baru dicuci $37.50 \%$. Membersihkan daging dicuci dulu baru dipotong $80 \%$, dipotong baru dicuci $20 \%$. Membersihkan ikan dicuci dulu baru dipotong $12.50 \%$, dipotong dulu baru dicuci $87.50 \%$. Mencuci beras 2 kali $90 \%$ > 2 kali sampai bersih airnya $10 \%$.

\section{Teknik pengolahan makanan}

Mengolah sayuran ditumis $37.50 \%$, direbus $42.50 \%$ dan digulai $20 \%$. Memasak nasi pada umumnya dengan rice cooker $62.50 \%$ dan panci $37.50 \%$ Pemakaian bumbu selalu $12.50 \%$, kadang-kadang $80 \%$ dan tidak pernah $7.50 \%$. Mengolah lauk pauk digoreng $70 \%$ dan digulai/ sop $30 \%$. Makanan anak balita dibeli $32.50 \%$ dan dibuat sendiri $67.50 \%$.

\section{Cara Penyajian dan pemberian makanan}

Pemilihan alat untuk penyajian sudah sesuai $62.50 \%$ dan tidak sesuai $37.50 \%$ Waktu makan 2 kali sehari 20\% dan 3 kali sehari $80 \%$. Penyajian makanandihidangkan di meja $80 \%$, ditikar $37.50 \%$ dan tidak dihidangkan $2.50 \%$. Cara makan di keluarga secara bersama 67.50\%, dan sendiri-sendiri $32.50 \%$ Pemberian makanan balita yang disuapi $60 \%$ dan makan sendiri $40 \%$.

\section{Pembahasan}

Berdasarkan deskripsi dan analisis data tentang sikap Ibu dalam pengaturan gizi atau makanan keluarga dapat dijelaskan bahwa secara keseluruhan sikap dan kebiasaan Ibu dalam pengaturan gizi keluarga sudah termasuk kategori baik. Hal ini ditinjau baik dari pengetahuan tentang zat gizi, pola makan, penyusunan menu, persiapan makanan, teknik pengolahan, penyajian dan pemberian makanan.

Pengetahuan ibu tentang zat-zat makanan sangat baik. Walupun pendidikan mereka pada umumnya (40\%) adalah SMP, tetapi mereka dapat memperoleh ilmu tentang zat-zat makanan dari posyandu yang ada di sekitar tempat tinggalnya. Selain itu, pada saat ini banyak media yang membahas tentang zat-zat makanan seperti koran, buku, tabloid, dan atau media elektronik. Sehingga hal ini berdampak pada bertambahnya pengetahuan mereka. Pengetahuan ini telah mereka terapkan dalam kehidupan sehari-harinya.

Sikap ibu tentang pengaturan makanan keluarga yang dalam hal berkaitan dengan pola makanan ternyata sangat baik. Berarti pola makan yang dilaksanakan ibu-ibu tersebut dalam keluarganya telah sesuai dengan yang dianjurkan pemerintah Indonesia yaitu Empat Sehat Lima Sempurna. Dengan telah baiknya pola makan keluarga ini berarti menggambarkan bahwa konsumsi makanan sehari-hari keluarga tersebut sudah sesuai dengan yang dibutuhkan oleh tubuh. Susunan makanan yang sesuai dengan pola makan bangsa Indonesia ini terdiri dari makanan pokok yang bersumber dari padi-padian, umbi-umbian, makanan laukpauk yang berasal dari hewan dan tumbuhtumbuhan, sayuran, buah-buahan dan susu.

Sikap Ibu dalam penyusunan menu makanan keluarga dikategorikan baik. Penyusunan menu ini juga ditunjang dari pengetahuan mereka tentang zat-zat makanan yang sangat baik. Dengan penyusunan menu makanan yang baik berarti memudahkan ibu-ibu rumahtangga khususnya yang memiliki balita dalam menyiapkan makanan keluarga. Selain itu juga dengan menyusun menu kita dapat menyajikan makanan keluarga lebih bervariasi dan tidak terjadi pengulangan jenis dan bahan makanan dalam waktu yang berdekatan.

Sebelum makanan disajikan perlu dilakukan persiapan. Persiapan yang dilakukan adalah pengupasan, pembersihan dan pengolahan. Dalam persiapan makanan keluarga. Ternyata persiapan yang dilakukan ibu-ibu tersebut termasuk dalam kategori baik. Berarti, ibu-ibu ini 
selalu melakukan persiapan sebelum makanan disajikan. Hal ini sesuai dengan pendapat Syahmien (1992) yang menyatakan bahwa sebelum memasak bahan makanan mengalami berbagai perlakukan, seperti dipotong, dikupas, diiris, dicincang dan direndam. Berbagai perlakukan itu akan mempengaruhi kandungan zat gizi dalam bahan makanan tersebut apabila dilakukan secara benar."

Dari kutipan itu terlihat bahwa persiapan bahan makanan yang salah akan mengakibatkan kehilangan zat gizi pada bahan makanan sehingga makanan yang dimakan tidak ada manfaatnya. Teknik pengolahan makanan yang dilakukan ibu-ibu tersebut. Dikategorikan baik. Hal ini berarti bahwa mereka selalu melakukan pengolahan sebelum makanan disajikan. Pengolahan makanan ini dilakukan ragam makanan mudah dicerna dan diproses dalam tubuh secara sempurna.

Sikap ibu tentang cara penyajian dan pemberian makanan sudah termasuk kategori sangat baik. Hal ini berarti bahwa ibu-ibu sudah melakukan penyajian dan pemberian yang sesuai dengan yang dinyatakan oleh Syahmien (1992) bahwa ada tiga hal pokok yang harus diperhatikan dalam penyajian makanan yaitu, pemilihan alat yang digunakan, cara menyusun makanan dalam penyajian dan menghias makanan tersebut.

\section{KESIMPULAN}

Setelah menganalisis data dari penelitian yang dilakukan pada ibu-ibu yang mempunyai balita penderita gizi buruk di Kecamatan Kuranji dapat disimpulkan bahwa sikap dan kebiasaan ibu dalam pengaturan gizi atau makanan keluarga sudah termasuk kategori baik. Berdasarkan hal tersebut berarti sikap dan kebiasaan ibu dalam pengaturan gizi atau makanan keluarga bukanlah merupakan faktor penyebab terjadinya gizi buruk balita di kecamatan Kuranji Kota Padang, mungkin faktor-faktor lain yang menyebabkan gizi buruk yang perlu dilakukan penelitian lanjutan.

Berdasarkan kesimpulan dapat disarankan (1) kepada pihak Dinas Kesehatan yang ada dilapangan, baik puskesmas dan posyandu untuk lebih meningkatkan penyuluhan tentang pengaturan gizi/makanan, (2) kepada pihak Dinas Kesehatan dan penelitian lainnya untuk melakukan penelitian lanjutan tentang pengaturan gizi/makanan ini dengan metode lain, seperti pengamatan langsung bagaimana ibuibu mengatur makanan keluarga secara langsung (observasi).

\section{DAFTAR PUSTAKA}

Fridayati L. 1997. Pengaruh Pemberian Makanan Tamabahan Terhadap Berat Badan. Tesis Magister, Universitas Airlangga, Surabaya.

Hartoyo, dkk. 2000. Identifikasi Faktor Yang Berpengaruh Terhadap Efektifitas Pemberian Makanan Tambahan Anak Dan Balita KEP di Kodya Bogor. Media Gizi Dan Keluarga. Jurusan GMSK Fakultas Pertanian IPB, Bogor.

Liswarti Y \& Elida. 2001. Studi tentang Penyakit Busung Lapar. Penelitian UNP, Padang.

Nasution, A \& Riyadi H. 1995. Gizi Terapan. Departemen Pendidikan dan Kebudayaan, Jakarta.

Nyoman I Dewa, dkk. Penilaian Status Gizi. EGC, Jakarta.

Syahmien M. 1992. Penyelenggaraan Makanan dan Institut dan Jasa Boga. Rajawali. Jakarta. 